\title{
Serum antibodies against genitourinary infectious agents in prostate cancer and benign prostate hyperplasia patients: a case-control study
}

\author{
Jan Hrbacek', Michael Urban ${ }^{1,5}$, Eva Hamsikova ${ }^{2}$, Ruth Tachezy ${ }^{2}$, Vaclav Eis ${ }^{3}$, Marek Brabec ${ }^{4}$, Jiri Heracek H. $^{1}$
}

\begin{abstract}
Background: Infection plays a role in the pathogenesis of many human malignancies. Whether prostate cancer (PCa) - an important health issue in the aging male population in the Western world - belongs to these conditions has been a matter of research since the $1970 \mathrm{~s}$. Persistent serum antibodies are a proof of present or past infection. The aim of this study was to compare serum antibodies against genitourinary infectious agents between PCa patients and controls with benign prostate hyperplasia (BPH). We hypothesized that elevated serum antibody levels or higher seroprevalence in PCa patients would suggest an association of genitourinary infection in patient history and elevated PCa risk.

Methods: A total of 434 males who had undergone open prostate surgery in a single institution were included in the study: 329 PCa patients and 105 controls with BPH. The subjects' serum samples were analysed by means of enzyme-linked immunosorbent assay, complement fixation test and indirect immunofluorescence for the presence of antibodies against common genitourinary infectious agents: human papillomavirus (HPV) 6, 11, 16, 18, 31 and 33, herpes simplex virus (HSV) 1 and 2, human cytomegalovirus (CMV), Chlamydia trachomatis, Mycoplasma hominis, Ureaplasma urealyticum, Neisseria gonorrhoeae and Treponema pallidum. Antibody seroprevalence and mean serum antibody levels were compared between cases and controls. Tumour grade and stage were correlated with serological findings.
\end{abstract}

Results: PCa patients were more likely to harbour antibodies against Ureaplasma urealyticum (odds ratio (OR) 2.06; 95\% confidence interval (Cl) 1.08-4.28). Men with BPH were more often seropositive for HPV 18 and Chlamydia trachomatis (OR 0.23; 95\% Cl 0.09-0.61 and OR 0.45; 95\% Cl 0.21-0.99, respectively) and had higher mean serum CMV antibody levels than PCa patients $(p=0.0004)$. Among PCa patients, antibodies against HPV 6 were associated with a higher Gleason score $(p=0.0305)$.

Conclusions: Antibody seropositivity against the analyzed pathogens with the exception of Ureaplasma does not seem to be a risk factor for PCa pathogenesis. The presence or higher levels of serum antibodies against the genitourinary pathogens studied were not consistently associated with PCa. Serostatus was not a predictor of disease stage in the studied population.

\section{Background}

Prostate cancer $(\mathrm{PCa})$ is one of the most important health issues in the aging male population, especially in the industrialized Western world. In the EU in 2006, it accounted for approximately $20 \%$ of all noncutaneous cancers [1]. In the United States, 217.730 new cases

\footnotetext{
* Correspondence: heracekj@seznam.cz

'Charles University in Prague, 3rd Faculty of Medicine, Department of Urology, Prague, Czech Republic

Full list of author information is available at the end of the article
}

were estimated to occur in 2010 (28\% of all new cancer cases in men except for basal and squamous cell skin carcinomas) and 32.050 men were expected to die from PCa (11\% of all cancer-related deaths) [2].

Research on the etiology of human cancer has found evidence for $15-20 \%$ of them being caused by an infectious agent. Whether PCa or at least a subgroup of $\mathrm{PCa}$ cases are associated with infection has been a matter of debate since the $1970 \mathrm{~s}$. With the widespread use of sophisticated serological assays and molecular biology

\section{Biomed Central}


methods for the detection of infectious agents in tissue, several studies have been published in the past two decades giving a better insight into the matter. Many of them have focused on a single pathogen only [3-9].

We have conducted an epidemiological study of several most common genitourinary pathogens among $\mathrm{PCa}$ and benign prostate hyperplasia ( $\mathrm{BPH})$ patients. The aim of the study was to elucidate whether the prevalence of antibody seropositivity and/or antibody levels differ between these two groups of patients. We hypothesized that elevated serum antibody levels or higher seroprevalence in PCa patients would suggest an association of genitourinary infection in patient history and elevated PCa risk.

\section{Methods}

\section{Study population}

This is a hospital-based case-control study. The study population consisted of a total of 434 Caucasian males who had been treated with open prostate surgery in the Department of Urology of the $3^{\text {rd }}$ Faculty of Medicine, Charles University in Prague in the period 2004-2010. The institution is a public hospital with a non-selective admission policy based on a defined catchment area. Patients underwent open radical retropubic prostatectomy (RRP) modified by Reiner and Walsh $[10,11]$ for clinically localized $\mathrm{PCa}$ or simple transvesical prostatectomy (SP) as described by Fuller and Culp $[12,13]$ for $\mathrm{BPH}$. No transurethral resection of the prostate (TURP) or needle-biopsy specimens were used in the study as both methods only deliver so little tissue that small foci of PCa can be missed. In 5 cases, percutaneous cystolithotripsy was performed along with SP. All patients were free of urinary tract infection symptoms and had a negative urine culture at the time of surgery. Those with untreatable bacteriuria (eg. for bladder stones and/or an indwelling catheter) were treated with antibiotics in the perioperative period.

Study population characteristics are summarized in Table 1. See patient flow diagram (Figure 1) for recruitment and pre-enrolment phase details.

A written informed consent, approved by the Internal Grant Agency of the Ministry of Health of the Czech Republic and by the Ethical Committee of the $3^{\text {rd }}$ Faculty of Medicine, Charles University in Prague (an IRB-like body which also approved the study), was obtained from all patients.

\section{Tissue sample handling}

Immediately after removal from the anatomical location, the specimens were referred to the Department of Pathology for examination: radical prostatectomy specimens were processed according to the scheme described by Montironi [14]: the external surface of the prostate
Table 1 The study population characteristics

\begin{tabular}{rcc}
\hline & \multicolumn{2}{c}{ Patient group } \\
\cline { 2 - 3 } & PCa & BPH \\
\hline Total number of patients & $\mathbf{3 2 9}$ patients & 105 patients \\
\hline Mean age (years) & $64(39-81)$ & $72(54-87)$ \\
\hline$<60$ & $76(23.1 \%)$ & $7(6.7 \%)$ \\
\hline $60-69$ & $191(58.1 \%)$ & $33(31.4 \%)$ \\
\hline $70-79$ & $61(18.5 \%)$ & $43(41.0 \%)$ \\
\hline$>79$ & $1(0.3 \%)$ & $22(21.0 \%)$ \\
\hline Mean PSA (ng/mL) & $9.0(0.8-35.4)$ & $7.5(0.9-39.0)$ \\
\hline $0-4.0$ & $37(11.5 \%)$ & $25(33.8 \%)$ \\
\hline $4.1-10.0$ & $176(54.8 \%)$ & $35(47.3 \%)$ \\
\hline $10.1-20.0$ & $94(29.3 \%)$ & $9(12.2 \%)$ \\
\hline$>20.0$ & $14(4.4 \%)$ & $5(6.7 \%)$ \\
\hline
\end{tabular}

Overall demographic and clinical characteristics of the studied population. PCa prostate cancer, BPH benign prostate hyperplasia, PSA prostate specific antigen.

was painted with ink to indicate surgical margins, seminal vesicles were amputated and embedded. Then the apical and bladder neck margins were removed and sectioned parallel to the urethra and submitted for the examination of margins. The rest of the prostate was sliced at $5 \mathrm{~mm}$ intervals perpendicularly to the urethra and examined. Tissue specimens obtained from transvesical prostatectomy were sectioned in $5 \mathrm{~mm}$ slices and representative sections from each lobe (a minimum of




three sections from each lobe, or one section per $10 \mathrm{~g}$ of tissue) were examined [15]. Tissue specimens were routinely fixed with $4 \%$ buffered formalin and embedded in paraffin. Microscopic slides were stained with hematoxylin and eosin and evaluated by optical microscopy. A single pathologist experienced in urogenital pathology performed microscopic evaluation of the slides. The morphological parameters were recorded as follows: histological type of cancer, if present (based on WHO classification [16]); Gleason score (GS) with primary, secondary and tertiary, if appropriate, grades (according to 2005 ISUP Consensus Conference [17]); pathological stage [18]; evaluation of tumour extension, local invasion into periprostatic tissue or seminal vesicles, perineural spread, venous and/or lymphatic vessel invasion and surgical margin status [19]. PCa was present in 329 surgical specimens, 105 were classified as $\mathrm{BPH}$ without any malignant structures. Table 2 summarizes GS and staging information for the PCa group. Fasting peripheral venous blood samples were drawn between 6 and 8 a.m. on the day of surgery and centrifuged at 2000 rpm for 20 minutes. The aliquots were kept frozen at $-80^{\circ} \mathrm{C}$ until analysis.

\section{Laboratory analyses}

The presence of antibodies to Chlamydia trachomatis (C. trachomatis), herpes simplex virus (HSV) 1 and 2, human cytomegalovirus (CMV), Neisseria gonorrhoeae (N. gonorrhoeae), Treponema pallidum (T. pallidum), Mycoplasma hominis (M. hominis) and Ureaplasma urealyticum (U. urealyticum) were detected by means of enzyme-linked immunoanalysis (ELISA), complement fixation test (CFT) or indirect immunofluorescence (IF) using commercially available, CE marked kits according to the manufacturers' recommendations. Table 3 gives a detailed description of the kits. Specific antibodies to HPV were detected by means of an in-house method

Table 2 Gleason score and tumour stage in prostate cancer cases

\begin{tabular}{cc}
\hline \multicolumn{2}{c}{ Tumour grading } \\
\hline Median Gleason score & 6 \\
\hline $2-6$ & $169(51.4 \%)$ \\
\hline 7 & $124(37.7 \%)$ \\
\hline $8-10$ & $36(10.9 \%)$ \\
\hline \multicolumn{2}{c}{ Tumour pathological stage } \\
\hline$\leq \mathrm{pT} 2 \mathrm{a}$ & $18(5.5 \%)$ \\
\hline $\mathrm{p} T 2 \mathrm{~b}$ & $5(1.5 \%)$ \\
\hline $\mathrm{pT2c}$ & $134(40.7 \%)$ \\
\hline $\mathrm{pT} 3 \mathrm{a}$ & $98(29.8 \%)$ \\
\hline$\geq \mathrm{pT3b}$ & $63(19.1 \%)$ \\
\hline $\mathrm{pTX}$ & $11(3.4 \%)$ \\
\hline
\end{tabular}

using virus-like particles (prepared in a recombinant baculovirus/insect cells system) as antigens [20]. Laboratory personnel were blinded to case/control status of the samples.

\section{Preparation of virus-like particles (VLPs)}

Insect cells Sf9 were grown in suspension cultures in TNM-FH insect medium (Sigma). About $4 \times 10^{9}$ of cells were infected by recombinant baculovirus at MOI 10 PFU per cell. Various recombinant baculoviruses carried the genetic information for L1 capsid protein of specific HPV types. Seventy-two hours after infection, the cells were harvested, washed with phosphate-buffered saline (PBS) and stored at $-20^{\circ} \mathrm{C}$. Cell pellets were resuspended in $40 \mathrm{ml}$ of extraction buffer $(10 \mathrm{mmol} / \mathrm{l}$ $\mathrm{MgCL}_{2}, 50 \mathrm{mmol} / \mathrm{l} \mathrm{CaCl}$, $150 \mathrm{mmol} / \mathrm{l} \mathrm{NaCl}, 0.01 \%$ Triton X-100, $20 \mathrm{mmol} / \mathrm{l}$ HEPES, $\mathrm{pH} \mathrm{7.4)}$ ) and sonicated $3 \times 30$ minutes on ice, the suspension was pelleted, the pellet was resuspended in $40 \mathrm{ml}$ of extraction buffer and sonication was repeated. Cesium chloride was added to combined supernatants to the final concentration of $30 \%$ and ultra-centrifuged for 22 hours at 45,000 rpm at $18^{\circ} \mathrm{C}$. The upper band was then separated by ultra centrifugation on $\mathrm{CsCl}$ step gradient (36\%-30.5\%-16\%) for 4 hours at $35,000 \mathrm{rev} / \mathrm{min}$. at $18^{\circ} \mathrm{C}$. The band was removed and subjected to SDS PAGE to determine protein concentration and Western blotting, and ELISA with corresponding VLP-specific monoclonal antibodies to prove the presence of the respective antigen.

\section{Detection of HPV-specific antibodies}

The presence of antibodies to the antigens derived from $\mathrm{HPV}$-specific proteins was tested using the enzymelinked immunosorbent assay (ELISA). VLPs mimicking HPV types $6,11,16,18,31$ and 33 were used as antigens. Briefly, wells of microtiter plates (Polysorp NUNC immunoplate, Thermo Fisher Scientific, Denmark) were coated with $50 \mu \mathrm{l}$ of purified VLP $(2 \mu \mathrm{g} / \mathrm{ml})$ in PBS at $37^{\circ} \mathrm{C}$ for 2 hours and at $+4^{\circ} \mathrm{C}$ overnight. All subsequent incubations were performed at $+37^{\circ} \mathrm{C}$ for 1 hour. Unbound antigen was removed, nonspecific binding sites were blocked by incubation with $1 \%$ bovine-serum albumin (BSA) in PBS, and the wells were incubated in duplicate with $100 \mu \mathrm{l}$ of human sera diluted 1:25 in washing buffer (PBS, $0.21 \mathrm{~mol} / \mathrm{l} \mathrm{NaCl}, 0.1 \%$ Triton X$100)$ with $1 \%$ of BSA. Following incubation, the antibodies bound were detected with donkey anti-human IgG ( $\mathrm{H}$ and $\mathrm{L}$ chain), covalently linked to horseradish peroxidase (Jackson ImmunoResearch Laboratories, Inc, West Grove, PA, USA), in the same buffer $(1: 7,500)$ and the reaction was visualized by adding $100 \mu \mathrm{l}$ of a substrate buffer $(50 \mathrm{mmol} / \mathrm{l}$ phosphate-citrate buffer, $\mathrm{pH}$ 5.0) containing $0.04 \%$ o-phenylenediamine and $0.006 \%$ hydrogen peroxide. The color reaction was stopped by $100 \mu \mathrm{l}$ of 
Table 3 Commercially available kits used for the detection of antibodies

\begin{tabular}{llll}
\hline Pathogen & Method & Kit & Manufacturer \\
\hline Cytomegalovirus & ELISA & ETI-CYTOK-G & DiaSorin S.p.A., Saluggia, Italy \\
\hline $\begin{array}{l}\text { Herpes simplex virus } \\
\text { type } 1\end{array}$ & ELISA & CaptiaTMHSV 1 IgG & Trinity Biotech plc, Bray, Ireland \\
\hline $\begin{array}{l}\text { Herpes simplex virus } \\
\text { type 2 }\end{array}$ & ELISA & HerpeSelect(R) 2 ELISA IgG & FOCUS Diagnostics, Cypress, CA, USA \\
\hline Chlamydia trachomatis & ELISA & Chlamydia Trachomatis IgG - & NovaTec Immunodiagnostica GmbH, Dietzenbach, \\
& & ELISA & Germany \\
\hline Mycoplasma hominis & Indirect immunofluorescence & $\begin{array}{l}\text { Anti-Mycoplasma Hominis IIFT } \\
\text { (IgG) }\end{array}$ & Eurolmmun, Lübeck, Germany \\
& test & Anti-Ureaplasma Urealyticum IIFT & Eurolmmun, Lübeck, Germany \\
\hline Ureaplasma urealyticum & Indirect immunofluorescence & (lgG) & \\
\hline Neisseria gonorrhoeae & Complement fixation test & Complement fixation test & Serion Immunodiagnostica GmbH, Würzburg, \\
& & Neisseria gonorhoeae & Germany \\
\hline Treponema pallidum & ELISA & Syphilis ElA II (TA] & Newmarket Laboratories Ltd, Kentford, UK \\
\hline
\end{tabular}

$2 \mathrm{~mol} / \mathrm{l} \mathrm{H}_{2} \mathrm{SO}_{4}$ and optical densities at 492 and $630 \mathrm{~nm}$ were read with an Infinite 200 microplate reader (TECAN, Austria). Background reactivity was determined in wells without antigen. Their absorbances were subtracted from the corresponding values obtained in the presence of antigen. Control sera known to be positive or negative were tested on each plate. The cut-off (CO) level, above which the optical density values were considered positive, was represented by a mean absorbance plus 2 standard deviations (SD) after eliminating the outliers - samples with absorbances higher than the calculated cut-off value - and the calculation was repeated until the absorbances of all remaining samples were lower. The means and SDs were calculated for each antigen/plate separately. All ELISA results are represented as a ratio between the absorbance obtained with the tested sample and the appropriate cut-off value (OD index), which expresses the strength of antibody response (antibody levels). To confirm the results, all samples within $10 \%$ above the $\mathrm{CO}$ value as well as about one quarter of all serum samples were retested. Samples with OD index values $\leq 1.0$ were considered not reactive.

\section{Statistical analyses}

Descriptive statistics was employed to assess demographic and clinical variables in all subjects. Local stage and tumour aggressiveness by GS were calculated in PCa patients.

We established seropositivity rates for each individual pathogen in cases and in controls. Percentages of seropositive individuals were compared using Fisher's exact test.

The mean serum antibody levels represented by OD indexes were calculated and compared between the two groups for HPV, HSV, CMV and C. trachomatis where ELISA allows for quantitative assessment using Wilcoxon's (nonparametric) test.
We were looking for a possible association between seropositivity and PSA level, seropositivity and tumour GS, and seropositivity and localized vs. locally advanced disease using appropriate logistic regression models. Throughout the paper, $5 \%$ significance level is meant whenever we mention statistical significance. All statistical analyses were computed using statistical software " $R$ " http://www.r-project.org/.

This paper's contents were developed with regard to current recommendations on reporting of observational studies [21].

\section{Results}

In a total of 434 study subjects, there were $329 \mathrm{PCa}$ patients (mean age 64 years) and 105 controls with $\mathrm{BPH}$ (mean age 72 years). $\mathrm{PCa}$ had been present in 11 patients out of 116 who underwent SP. These incidental carcinomas were included in the PCa group for case vs. control comparisons but were excluded from analyses where exact local staging was required (see Figure 1). The mean PSA levels were 9.0 and $7.5 \mathrm{ng} / \mathrm{mL}$ among subjects and controls, respectively (Table 1). Among PCa patients, $47.7 \%$ were diagnosed with localized disease and $52.3 \%$ had locally advanced cancer. One half of the tumours (51.4\%) were low-grade lesions GS 2-6, while one tenth (10.9\%) were high-grade lesions GS 810 (Table 2).

The seropositivity rates and mean serum antibody levels are summarized in Table 4. U. urealyticum antibodies were significantly more common in $\mathrm{PCa}$ cases than in controls (OR 2.06; 95\% CI 1.08-4.28). Conversely, the seropositivity rates for HPV 18 and C. trachomatis were significantly higher in $\mathrm{BPH}$ patients than in the PCa group using Fisher's exact test (OR 0.23; 95\% CI $0.09-0.61$ and OR 0.45 ; 95\% CI 0.21-0.99, respectively). The mean serum antibody levels for CMV were higher in the $\mathrm{BPH}$ than in the $\mathrm{PCa}$ group using 
Table 4 Antibody seropositivity rates and mean serum antibody levels

\begin{tabular}{|c|c|c|c|c|c|c|c|}
\hline & \multicolumn{4}{|c|}{ Seroprevalence rate } & \multicolumn{3}{|c|}{ Mean serum levels OD/CO } \\
\hline & $\mathrm{PCa}$ & BPH & OR & $95 \% \mathrm{Cl}$ & $\mathrm{PCa}$ & $\mathrm{BPH}$ & $p$ \\
\hline HPV 6 & $77(24.1 \%)$ & $21(20.8 \%)$ & 1.21 & $0.71-2.12$ & 2.608 & 3.162 & 0.0964 \\
\hline HPV 11 & $40(12.5 \%)$ & $15(14.9 \%)$ & 0.82 & $0.44-1.60$ & 2.554 & 2.259 & 0.9698 \\
\hline HPV 16 & $16(5.0 \%)$ & $10(9.9 \%)$ & 0.48 & $0.21-1.13$ & 3.470 & 3.251 & 0.8743 \\
\hline HPV 18 & $8(2.5 \%)$ & $10(9.9 \%)$ & 0.23 & $0.09-0.61$ & 1.496 & 1.365 & 0.9290 \\
\hline$\overline{H P V} 31$ & $19(5.9 \%)$ & $8(7.9 \%)$ & 0.73 & $0.32-1.83$ & 2.616 & 3.640 & 0.1053 \\
\hline HPV 33 & $7(2.2 \%)$ & $5(5.0 \%)$ & 0.43 & $0.13-1.48$ & 2.156 & 3.620 & 0.3434 \\
\hline$C M V$ & $264(80.2 \%)$ & $91(86.7 \%)$ & 0.62 & $0.32-1.14$ & 3.839 & 4.407 & 0.0004 \\
\hline HSV 1 & $313(95.1 \%)$ & $99(94.3 \%)$ & 1.19 & $0.42-2.97$ & 3.760 & 3.832 & 0.9649 \\
\hline HSV 2 & $42(12.8 \%)$ & $14(13.3 \%)$ & 0.95 & $0.51-1.88$ & 5.362 & 4.859 & 0.8056 \\
\hline Chlamydia trachomatis & $18(5.5 \%)$ & $12(11.4 \%)$ & 0.45 & $0.21-0.99$ & 1.281 & 1.210 & 0.6560 \\
\hline Mycoplasma hominis & $60(18.2 \%)$ & $15(14.3 \%)$ & 1.34 & $0.74-2.55$ & NA & NA & - \\
\hline Ureaplasma urealyticum & $64(19.5 \%)$ & $11(10.5 \%)$ & 2.06 & $1.08-4.28$ & NA & NA & - \\
\hline Neisseria gonorrhoeae & $20(6.1 \%)$ & $6(5.7 \%)$ & 1.07 & $0.44-2.99$ & NA & NA & - \\
\hline Treponema pallidum & $1(0.3 \%)$ & $0(0 \%)$ & NA & NA & NA & NA & - \\
\hline
\end{tabular}

Antibody seropositivity rates for different genitourinary pathogens in cases and controls. Only reactive serum samples $(\mathrm{OD} / \mathrm{CO}>1.0)$ were considered for the calculation of mean serum antibody levels. PCa prostate cancer, BPH benign prostate hyperplasia, OR odds ratio, $\mathrm{Cl}$ confidence interval, OD/CO optical density/ cut-off, HPV human papillomavirus, CMV human cytomegalovirus, HSV herpes simplex virus, NA not applicable.

Wilcoxon's test (4.407 vs. 3.839; $\mathrm{p}=0.0004$; see Table 4). For other pathogens, the differences in the seroprevalence and mean serum antibody levels were not statistically significant (Figure 2).

We then analyzed the PCa cases alone with regard to serostatus and disease characteristics. Patients seropositive for HPV 6 were more likely to have higher GS than men without antibodies to HPV 6 (mean GS 6.45 vs. 6.75; $\mathrm{p}=0.0305$ ); other differences in GS were not demonstrated. No statistically significant difference was noted in the mean PSA level between the seropositive and seronegative (for each pathogen) individuals. The mean serum antibody levels did not differ significantly between the patients with localised disease $(\leq \mathrm{pT} 2 \mathrm{c})$ and locally advanced PCa ( $\geq \mathrm{pT} 3 \mathrm{a})$. These observations did not change when age was taken as an additional variable and linear/logistic regression models were employed (data not shown).

\section{Discussion}

Clinically insignificant foci of PCa are harboured by prostates of $80 \%$ of men over 80 years old [22]. The only way to examine the prostate in its entirety and to divide the subjects into the case and control groups is the use of open surgery derived specimens. This approach has not been used so far. No needle biopsy or TURP which can only deliver a small portion of prostatic tissue allows the clinician to rule out the possibility of cancer being present in the rest of the prostate gland. Approximately 1/10 of allegedly benign prostates scheduled by a surgeon for SP turned out as cancerous in our study, which is in line with the 4-20\% incidental prostate cancer rate cited in the literature [23]. Most of the previous studies identified cases in cancer registries while controls were defined either by absence of $\mathrm{PCa}$ diagnosis [7,24-27] or as "cancer free" at the time of analysis $[6,8,28]$. This approach can be misleading, because it is the nature of the disease to evolve as subclinical lesions for years or even decades and inclusion of these patients into the control group may have biased the results towards the null. Only few authors assessed the controls more deeply, i.e. by histopathologic examination of prostate tissue [3-5,29,30] obtained by open surgery, TURP or prostate biopsy. Inherently, a needle biopsy or TURP can only confirm but by no means exclude the diagnosis of cancer. Some researchers gathered details of tumour characteristics such as GS and staging by TNM classification $[5,8,26,28-32]$, but in most cases they do not report these data.

The exclusive use of radical prostatectomy-derived specimens allowed for the assessment of seropositivity with regard to exact local staging of the disease. This is the first study to our knowledge to look at the issue so closely. Had there been an association between local disease stage and serostatus, it would have been demonstrated. However, no statistically significant differences were noted. Similarly, no differences were found in the mean PSA levels and mean GS between the seropositive and seronegative PCa patients (with the exception of HPV 6, as mentioned above and discussed later on in this section). The picture remained the same when age was taken as an additional variable. 


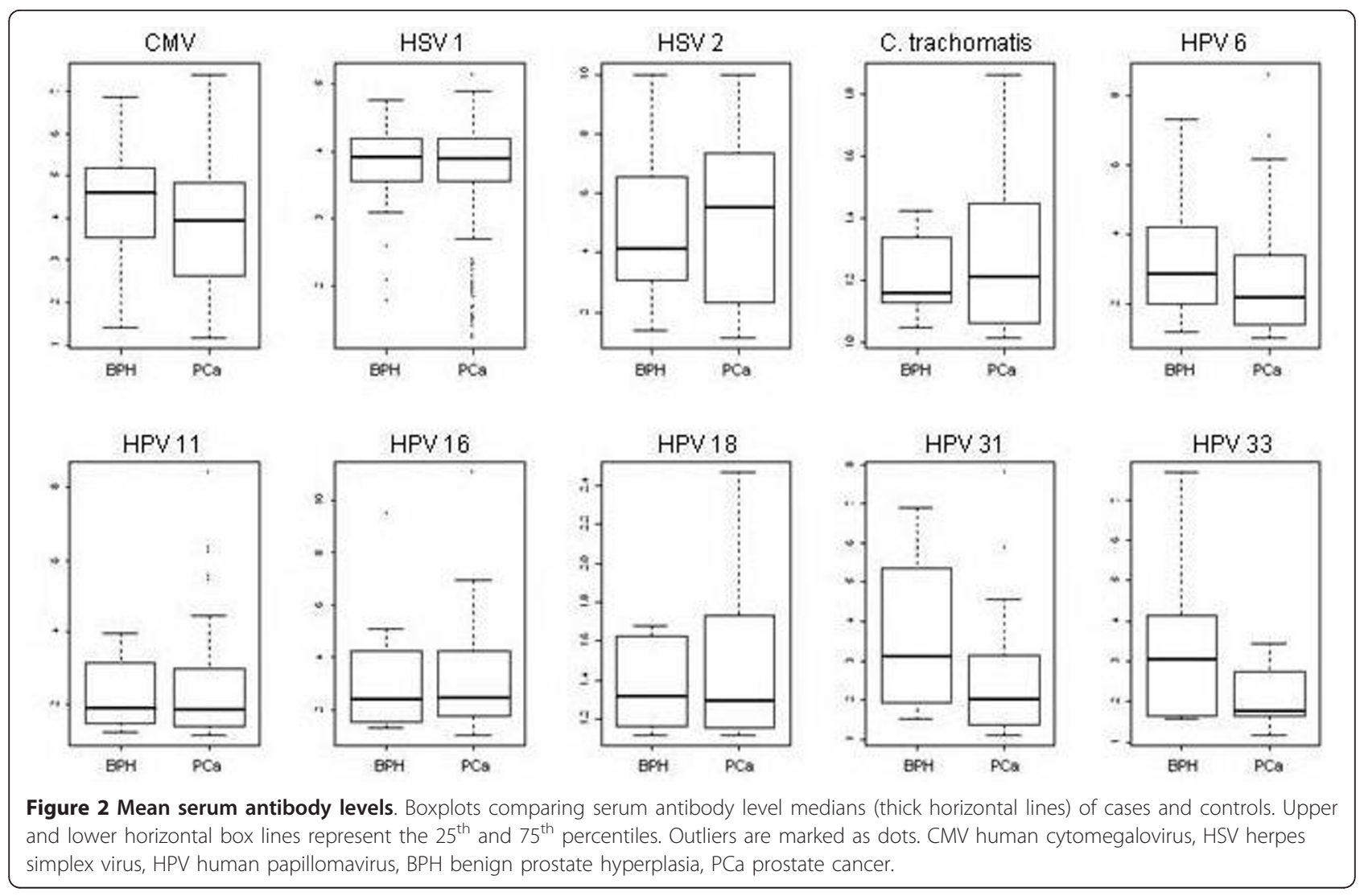

Since the 1950s when Ravich and Ravich [33] hypothesized that PCa could be caused by an infectious agent, research studies have been conducted in order to confirm or rule out this possibility. Taylor et al. reviewed the literature related to sexually transmitted diseases (STDs) and PCa from 1966 to 2004 identifying 6022 unique PCa cases and 7320 controls and concluded that having had any STD was associated with an elevated PCa risk: odds ratio (OR) of 1.48, 95\% confidence interval (CI) 1.26-1.73 [34]. A large recent prospective study by Huang et al., however, did not find an association of PCa with a specific STD and a borderline association with any vs. none [26]. Whereas $C$. trachomatis, HPV 16 and 18, HSV 2, CMV and human herpesvirus 8 were ascertained by serology in this study, a history of syphilis and gonorrhoea was only selfreported.

HPV is a sexually transmitted pathogen which has been the most extensively investigated one because of its association with cervical and a part of other anogenital neoplasms [32]. We have identified 12 epidemiological studies related to HPV and PCa, a vast majority of them being case-control studies putting together over 4,700 PCa cases and 7,300 controls. No more than two of them [24,29] found an association between PCa and HPV 18 and 33, respectively, whereas the others did not (see Table 5 for details). In our study population, HPV 18 antibodies were more common in men with $\mathrm{BPH}$ than in PCa patients. Such an inverse association has not been reported so far.

The seropositivity rates reported in our study were $5.0 \%$ and $2.5 \%$ in PCa patients for HPV 16 and 18 , respectively, and $9.9 \%$ for both antigens in the $\mathrm{BPH}$ group (Table 4). This coincides well with the estimated 10.2\% HPV 16 seroprevalence in the US male population aged 50-59 years [35].

HPV 6 is associated with benign skin lesions of the genitourinary tract. This genotype was demonstrated in up to $90 \%$ of genital warts [36]. To our knowledge, no previous study investigated the association of HPV $6 / 11$ and $\mathrm{PCa}$ nor suggested the virus' potential to induce a more malignant phenotype of PCa cells. However, these two serotypes have been associated with malignant transformation of recurrent respiratory papillomatosis [37]. Our finding of a higher mean GS, i.e. increased aggressiveness of the prostate tumour in the presence of HPV 6 antibodies, would require further validation.

Infection with certain herpesviruses has been associated with several human cancers. A link has been found between HSV 1 and oral cancer, while HSV 2 seems to be a cofactor to HPV in the etiology of invasive cervical 
Table 5 Overview of previously published case-control serologic studies of genitourinary pathogens with regard to prostate cancer risk

\begin{tabular}{|c|c|c|c|c|c|c|c|c|c|c|}
\hline Author & Year & $\begin{array}{l}\text { Pathogen } \\
\text { studied }\end{array}$ & $\begin{array}{c}\text { No. of } \\
\text { subjects with } \\
\text { PCa }\end{array}$ & $\begin{array}{l}\% \text { sero- } \\
\text { positive }\end{array}$ & $\begin{array}{l}\text { No. of controls } \\
\text { without PCa }\end{array}$ & $\begin{array}{l}\% \text { sero- } \\
\text { positive }\end{array}$ & $\begin{array}{l}\text { RR/ } \\
\text { OR }\end{array}$ & $\begin{array}{l}95 \% \\
\mathrm{Cl}\end{array}$ & $\begin{array}{l}\text { Evidence of } \\
\text { association }\end{array}$ & Method \\
\hline \multirow[t]{3}{*}{$\begin{array}{l}\text { Sutcliffe } \\
{[30]}\end{array}$} & 2010 & HPV 16 & 616 & 14.5 & 616 & 13.7 & $\begin{array}{c}\text { OR } \\
1.07\end{array}$ & $\begin{array}{l}0.77- \\
1.48\end{array}$ & no & ELISA \\
\hline & & HPV 18 & 616 & 3.3 & 616 & 3.7 & $\begin{array}{c}\text { OR } \\
0.87 \\
\end{array}$ & $\begin{array}{l}0.47- \\
1.63 \\
\end{array}$ & no & \\
\hline & & $\overline{\text { HPV } 31}$ & 616 & 12.3 & 616 & 10.8 & $\begin{array}{c}\text { OR } \\
1.15\end{array}$ & $\begin{array}{l}0.8- \\
1.64 \\
\end{array}$ & no & \\
\hline $\begin{array}{l}\text { Dennis } \\
{[27]}\end{array}$ & 2009 & HPV 16/18 & 267 & 18.7 & 267 & 16.9 & $\begin{array}{c}\text { OR } \\
1.13 \\
\end{array}$ & $\begin{array}{l}0.73- \\
1.75 \\
\end{array}$ & no & ELISA \\
\hline \multirow[t]{2}{*}{ Huang [26] } & 2008 & HPV 16 & 765 & 10.1 & 915 & 10.6 & $\begin{array}{l}\text { OR } \\
0.9 \\
\end{array}$ & $\begin{array}{l}0.7- \\
1.3 \\
\end{array}$ & no & ELISA \\
\hline & & HPV 18 & 765 & 9.4 & 915 & 8.1 & $\begin{array}{l}\text { OR } \\
1.2 \\
\end{array}$ & $\begin{array}{l}0.8- \\
1.7 \\
\end{array}$ & no & \\
\hline Sitas [9] & 2007 & HPV 16 & 205 & 68.0 & 673 & 58.0 & $\begin{array}{c}\mathrm{OR} \\
1.33 \\
\end{array}$ & $\begin{array}{l}0.86- \\
2.07 \\
\end{array}$ & no & ELISA \\
\hline \multirow[t]{3}{*}{$\begin{array}{l}\text { Sutcliffe } \\
\text { [28] }\end{array}$} & 2007 & HPV 16 & 691 & 7.5 & 691 & 8.8 & $\begin{array}{c}\text { OR } \\
0.83 \\
\end{array}$ & $\begin{array}{l}0.57- \\
1.23 \\
\end{array}$ & no & ELISA \\
\hline & & HPV 18 & 691 & 6.1 & 691 & 5.8 & $\begin{array}{c}\mathrm{OR} \\
1.04 \\
\end{array}$ & $\begin{array}{l}0.66- \\
1.64 \\
\end{array}$ & no & \\
\hline & & HPV 33 & 691 & 7.2 & 691 & 6.4 & $\begin{array}{c}\text { OR } \\
1.14\end{array}$ & $\begin{array}{l}0.76- \\
1.72\end{array}$ & no & \\
\hline \multirow[t]{3}{*}{ Korodi [8] } & 2005 & HPV 16 & 799 & 6.0 & 2596 & 6.0 & $\begin{array}{l}\text { OR } \\
0.9 \\
\end{array}$ & $\begin{array}{l}0.64- \\
1.26 \\
\end{array}$ & no & ELISA \\
\hline & & HPV 18 & 799 & 3.0 & 2595 & 4.0 & $\begin{array}{c}\text { OR } \\
0.79 \\
\end{array}$ & $\begin{array}{l}0.49- \\
1.26 \\
\end{array}$ & no & \\
\hline & & HPV 33 & 800 & 9.0 & 2596 & 7.0 & $\begin{array}{c}\text { OR } \\
0.99 \\
\end{array}$ & $\begin{array}{l}0.72- \\
1.38 \\
\end{array}$ & no & \\
\hline \multirow[t]{3}{*}{ Adami [29] } & 2003 & HPV 16 & 238 & 13.0 & 210 & 15.0 & $\begin{array}{l}\text { OR } \\
0.7 \\
\end{array}$ & $\begin{array}{l}0.4- \\
1.3 \\
\end{array}$ & no & ELISA \\
\hline & & HPV 18 & 238 & 12.0 & 210 & 12.0 & $\begin{array}{l}\text { OR } \\
0.9 \\
\end{array}$ & $\begin{array}{l}0.5- \\
1.9 \\
\end{array}$ & no & \\
\hline & & HPV 33 & 238 & 29.0 & 210 & 23.0 & $\begin{array}{l}\text { OR } \\
1.6 \\
\end{array}$ & $\begin{array}{l}1.0- \\
2.7 \\
\end{array}$ & yes & \\
\hline \multirow[t]{2}{*}{$\begin{array}{l}\text { Rosenblatt } \\
\text { [32] }\end{array}$} & 2003 & HPV 16 & 642 & 9.2 & 570 & 8.8 & $\begin{array}{c}\mathrm{OR} \\
1.06 \\
\end{array}$ & $\begin{array}{l}0.71- \\
1.57 \\
\end{array}$ & no & ELISA \\
\hline & & HPV 18 & 642 & 3.4 & 570 & 2.5 & $\begin{array}{c}\mathrm{OR} \\
1.36 \\
\end{array}$ & $\begin{array}{l}0.69- \\
2.69 \\
\end{array}$ & no & \\
\hline Hayes [31] & 2000 & HPV 16 & 276 & 6.9 & 295 & 5.1 & $\begin{array}{l}\text { OR } \\
1.4 \\
\end{array}$ & $\begin{array}{l}0.7- \\
2.8 \\
\end{array}$ & no & ELISA \\
\hline Hisada [6] & 2000 & HPV 16 & 48 & 42.0 & 63 & 30.0 & $\begin{array}{l}\text { OR } \\
2.7 \\
\end{array}$ & $\begin{array}{l}0.9- \\
7.9 \\
\end{array}$ & no & ELISA \\
\hline \multirow[t]{3}{*}{ Dillner [23] } & 1998 & HPV 16 & 165 & 4.0 & 290 & 2.0 & $\begin{array}{l}\text { RR } \\
2.4 \\
\end{array}$ & $\begin{array}{l}0.75- \\
7.58 \\
\end{array}$ & no & ELISA \\
\hline & & HPV 18 & 165 & 10.0 & 290 & 4.0 & $\begin{array}{l}\text { RR } \\
2.6\end{array}$ & $\begin{array}{l}1.17- \\
5.75 \\
\end{array}$ & yes & \\
\hline & & HPV 33 & 164 & 4.0 & 289 & 6.0 & $\begin{array}{l}\mathrm{RR} \\
0.7 \\
\end{array}$ & $\begin{array}{l}0.26- \\
1.66 \\
\end{array}$ & no & \\
\hline Strickler [5] & 1998 & HPV 16 & 63 & 1.6 & 144 & 4.9 & NS & NS & no & ELISA \\
\hline $\begin{array}{l}\text { Dennis } \\
{[26]} \\
\end{array}$ & 2009 & $\begin{array}{l}\text { Ch. } \\
\text { trachomatis }\end{array}$ & 267 & 14.6 & 267 & 11.6 & $\begin{array}{c}\mathrm{OR} \\
1.35 \\
\end{array}$ & $\begin{array}{l}0.79- \\
2.31 \\
\end{array}$ & no & $\begin{array}{l}\text { Microimmuno- } \\
\text { fluorescence }\end{array}$ \\
\hline Huang [25] & 2008 & $\begin{array}{l}\text { Ch. } \\
\text { trachomatis }\end{array}$ & 765 & 11.2 & 915 & 9.7 & $\begin{array}{l}\text { OR } \\
1.2 \\
\end{array}$ & $\begin{array}{l}0.9- \\
1.6 \\
\end{array}$ & no & ELISA \\
\hline $\begin{array}{l}\text { Sutcliffe } \\
\text { [27] }\end{array}$ & 2007 & $\begin{array}{l}\text { Ch. } \\
\text { trachomatis }\end{array}$ & 691 & 4.0 & 691 & 3.5 & $\begin{array}{c}\text { OR } \\
1.13\end{array}$ & $\begin{array}{l}0.65- \\
1.96\end{array}$ & no & ELISA \\
\hline
\end{tabular}


Table 5 Overview of previously published case-control serologic studies of genitourinary pathogens with regard to prostate cancer risk (Continued)

\begin{tabular}{|c|c|c|c|c|c|c|c|c|c|c|}
\hline Antilla [7] & 2005 & $\begin{array}{l}\text { Ch. } \\
\text { trachomatis }\end{array}$ & 738 & 7.5 & 2271 & 10.5 & $\begin{array}{c}\mathrm{OR} \\
0.69\end{array}$ & $\begin{array}{l}0.51- \\
0.94\end{array}$ & yes* & $\begin{array}{l}\text { Microimmuno- } \\
\text { fluorescence }\end{array}$ \\
\hline Dillner [24] & 1998 & $\begin{array}{l}\text { Ch. } \\
\text { trachomatis }\end{array}$ & 165 & 10.9 & 290 & 10.7 & $\begin{array}{l}\mathrm{RR} \\
1.04\end{array}$ & $\begin{array}{l}0.54- \\
2.00\end{array}$ & no & $\begin{array}{l}\text { Microimmuno- } \\
\text { fluorescence }\end{array}$ \\
\hline Hayes [31] & 2000 & T. pallidum & 271 & 10.7 & 286 & 6.3 & $\begin{array}{l}\mathrm{OR} \\
1.8\end{array}$ & $\begin{array}{l}1.0- \\
3.5\end{array}$ & yes & $\begin{array}{l}\text { Microhemagglut-ination } \\
\text { assay (MHA-TP) }\end{array}$ \\
\hline $\begin{array}{l}\text { Dennis } \\
\text { [27] }\end{array}$ & 2009 & HSV 2 & 267 & 28.5 & 267 & 20.6 & $\begin{array}{l}\mathrm{OR} \\
1.6\end{array}$ & $\begin{array}{l}1.05- \\
2.44\end{array}$ & yes & ELISA \\
\hline Huang [26] & 2008 & HSV 2 & 765 & 9.2 & 915 & 9.7 & $\begin{array}{l}\mathrm{OR} \\
0.9\end{array}$ & $\begin{array}{l}0.7- \\
1.3\end{array}$ & no & $\begin{array}{l}\text { enzymatic immunodot } \\
\text { assay }\end{array}$ \\
\hline Korodi [25] & 2005 & HSV 2 & 163 & 7.2 & 288 & 7.5 & $\begin{array}{c}\mathrm{OR} \\
0.93\end{array}$ & $\begin{array}{c}0.44- \\
1.96\end{array}$ & no & ELISA \\
\hline Baker [4] & 1981 & HSV 2 & 50 & 68.0 & 159 & 51.0 & NS & NS & yes & $\begin{array}{l}\text { indirect } \\
\text { hemagglutination } \\
\text { inhibition test }\end{array}$ \\
\hline Herbert [3] & 1976 & HSV 2 & 28 & 71.4 & 29 & 65.5 & NS & NS & no & $\begin{array}{l}\text { microcomplement } \\
\text { fixation test }\end{array}$ \\
\hline Huang [26] & 2008 & CMV & 765 & 70.3 & 915 & 68.4 & $\begin{array}{l}\mathrm{OR} \\
1.1\end{array}$ & $\begin{array}{c}0.9- \\
1.3\end{array}$ & no & ELISA \\
\hline
\end{tabular}

OR odds ratio, RR relative risk, $\mathrm{Cl}$ confidence interval, HPV human papillomavirus, HSV herpes simplex virus, CMV human cytomegalovirus, ELISA Enzyme-linked Immunosorbent Assay, NS not specified, * inverse association.

cancer [38]. Sexual transmission of HSV 1 and 2 leading to infection of the genitourinary tract is a commonplace. HSV 2 is seldom completely cleared from the body. Antibody levels may fluctuate over time, especially after clinical relapses, but the exact dynamics is not known [27]. In the U.S., $51.0 \%$ of persons over 12 years were seropositive for HSV 1, 5.3\% for HSV 2 and in 16.6\%, antibodies specific to both virus types were present [39]. The HSV 2 prevalence is highest in some African countries, reaching $80 \%$ in persons $\geq 35$ years $[40]$.

Sexual contact is a major route of CMV transmission in adults. Increased CMV rates are associated with increased history of sexually transmitted diseases. Recent data indicate that CMV has multiple oncogenic properties: it promotes mutagenesis, angiogenesis and cell invasion [41]. The CMV seroprevalence increases with age, reaching approximately $91 \%$ among persons older than 80 years [42]. Little is known about the relationship between CMV and PCa risk. The only relevant study we have identified did not show evidence of an association of CMV seropositivity and PCa incidence [26]. Our data suggest that PC cases have lower antibody levels against CMV than $\mathrm{BPH}$ patients.

C. trachomatis is one of the most common bacterial STDs worldwide. It causes urethritis, epididymitis and prostatitis in males. In up to $50 \%$ of infected men and $70-80 \%$ of infected women, the infection is clinically inapparent [43]. In four recent epidemiological studies of several hundred cases and controls each [24,26-28], no association between chlamydial antibodies and $\mathrm{PCa}$ was found. One large study [7], however, shows a significant inverse association (OR 0.69, 95\% CI 0.510.94) between chlamydial antibodies and PCa and so do our data. The seroprevalence we have established is concordant with the data reported previously [44].

The increased antibody prevalence and higher serum antibody levels we are reporting do not suggest the role of infection in $\mathrm{PCa}$ pathogenesis. They do indirectly support a concept of $\mathrm{BPH}$ being product of immune inflammatory processes, an idea based on a growing amount of evidence [45]. The trigger point for an increased and possibly self-repeating, pathological immune response would be infection of the genitourinary tract by these pathogens [46].

A study of Takeyama suggested that M. hominis can trigger inflammation in the prostate by inducing interleukin-8 secretion [47]. Chronic infection by M. genitalium and M. hyorhinis of human prostate cells resulted in alteration of karyotypes (notably increased polysomy) and malignant transformation in vitro. Inoculated in nude mice, these cell lines initiated tumour growth [48]. We have not identified any study concerned with the clinical association between PCa and Mycoplasma and/ or Ureaplasma. To our knowledge, we are the first to report an increased seroprevalence of $U$. urealyticum antibodies in PCa patients compared to men with $\mathrm{BPH}$.

Gonorrhoea and syphilis are historically most notorious STD's. In a large prospective cohort study of Sutcliffe et al., gonorrhoea and syphilis were self-reported in $3 \%$ and $0.2 \%$, respectively, and no relationship with PCa was observed [49]. Self-report of gonorrhoea and/or syphilis was associated with PCa (OR 1.6, 95\% CI 1.2-2.1) in a 
study of Hayes et al. Of note, however, serologic evidence of T. pallidum infection was found in $9.9 \%$ vs. $2 \%$ reported (in the black population) and $3.2 \%$ vs. $0.1 \%$ reported (in whites) [31]. This fact illustrates how unreliable questionnaire and interview-based studies can be whether for recall bias, unwillingness to report a socially embarrassing disease such as STD or just by ignorance, i. e. failing to classify a condition as STD.

Our seroprevalence data for T. pallidum and $\mathrm{N}$. gonorrhoeae are comparable for $\mathrm{PCa}$ and $\mathrm{BPH}$ patients. However, the statistical power is low due to the small number of patients to draw any reasonable conclusions.

Every research paper has its limitations and so does ours. Because blood samples were drawn after the diagnosis of PCa, we cannot state whether contact with the pathogen preceded or followed the evolution of cancer. Taking BPH patients as controls brings the risk of not coming to a meaningful conclusion if both conditions had the same (shared) etiology. On the other hand, virtually no healthy prostates exist in the age group our patients belong to.

\section{Conclusions}

This is the first study to our knowledge to demonstrate a higher $\mathrm{U}$. urealyticum seroprevalence rate in PCa patients when compared to BPH controls. HPV 18 and $\mathrm{C}$. trachomatis seropositivity was more common and the mean CMV antibody levels were higher in the control $(\mathrm{BPH})$ group than among $\mathrm{PCa}$ cases. Unlike other research groups, we used open surgeryderived specimens exclusively for all analyses. This allowed us 1) to minimise the likelihood of misclassifying a tissue sample as benign if cancer was present and 2) to look for a correlation of PCa and infection in subgroups of patients depending on local disease stage. This novel type of analysis did not demonstrate any differences.

Disregarding inconsistencies of results of the previous studies, this one adds to the growing body of evidence that the presence or higher levels of serum antibodies to most of the genitourinary pathogens studied are not associated with an elevated PCa risk and/or a more malignant tumour behavior. Antibody seropositivity to these infectious agents does not emerge as a risk factor in screening or treatment decision making. Tissue analyses focused on viral or bacterial DNA presence could be a track to run to cast light onto possible association between $\mathrm{PCa}$ and infectious agents.

\section{Acknowledgements}

The study was funded by the Internal Grant Agency of the Ministry of Health, grant no. NS9984.

\section{Author details}

${ }^{1}$ Charles University in Prague, 3rd Faculty of Medicine, Department of Urology, Prague, Czech Republic. ${ }^{2}$ Institute of Hematology and Blood Transfusion, Praque, Czech Republic. ${ }^{3}$ Charles University in Praque, 3rd Faculty of Medicine, Department of Pathology, Prague, Czech Republic. ${ }^{4}$ Institute of Computer Science, Academy of Sciences of the Czech Republic, Department of Nonlinear Modelling, Prague, Czech Republic. ${ }^{5}$ Androgeos, Prague, Czech Republic.

\section{Authors' contributions}

$\mathrm{JHr}$ participated in the study design, recruited the patients, reviewed the literature and drafted the manuscript. JHe and MU conceived the study design, recruited the patients and reviewed the whole manuscript. MU performed most of the surgeries. EH and RT carried out the immunoassays and wrote the appropriate part of the Methods section. VE carried out the histopathological examinations. MB performed the statistical analyses and covered that part in the text. All authors read and approved the final version of the manuscript.

\section{Authors' information}

$\mathrm{JHr}$ is a PhD student of the $3^{\text {rd }}$ Faculty of Medicine, Charles University, Prague; this work represents a part of his thesis. JHe is a research fellow at the same institution. EH is the head of the Laboratory for Prevention of Viral Infections, Institute of Hematology and Blood Transfusion. MU is the head of the Department of Urology of the $3^{\text {rd }}$ Faculty of Medicine, Charles University, Prague.

\section{Competing interests}

The authors declare that they have no competing interests.

Received: 19 October 2010 Accepted: 3 February 2011

Published: 3 February 2011

\section{References}

1. Marberger M: Prostate cancer 2008: Challenges in diagnosis and management. Eur Urol Suppl 2009, 3:89-96.

2. Jemal A, Siegel R, Xu J, Ward E: Cancer Statistics, 2010. CA Cancer J Clin 2010, 60:277-300.

3. Herbert JT, Birkhoff JD, Feorino PM, Caldwell GG: Herpes simplex virus type 2 and cancer of the prostate. J Urol 1976, 116:611-612.

4. Baker LH, Mebust WK, Chin TDY, Chapman AL, Hinthorn D, Towle D: The relationship of herpesvirus to carcinoma of the prostate. J Urol 1981, 125:370-374.

5. Strickler HD, Burk R, Shah K, Viscidi R, Jackson A, Pizza G, Bertoni F, Schiller JT, Manns A, Metcalf R, Qu W, Goedert JJ: A multifaceted study of human papillomavirus and prostate carcinoma. Cancer 1998, 82(6):1118-1125.

6. Hisada M, Rabkin CS, Strickler HD, Wright WE, Christianson RE, van den Berg BJ: Human papillovirus antibody and risk of prostate cancer. JAMA 2000, 3:340-341.

7. Antilla T, Tenkanen L, Lumme S, Leinonen M, Gislefoss RE, Hallmans G, Thoresen S, Hakulinen T, Luostarinen T, Stattin P, Saikku P, Dillner J, Lehtinen M, Hakama M: Chlamydial antibodies and risk of prostate cancer. Cancer Epidemiol Biomarkers Prev 2005, 14(2):385-389.

8. Korodi Z, Dillner J, Jellum E, Lumme S, Hallmans G, Thoresen S, Hakulinen T, Stattin P, Luostarinen T, Lehtinen M, Hakama M: Human papillomavirus 16, 18, and 33 infections and risk of prostate cancer: a Nordic nested casecontrol study. Cancer Epidemiol Biomarkers Prev 2005, 14(12):2952-2955.

9. Sitas F, Urban M, Stein L, Beral V, Ruff P, Hale M, Patel M, O'Connell D, Yu XQ, Verzijden A, Marais D, Williamson AL: The relationship between anti-HPV-16 lgG seropositivity and cancer of the cervix, anogenital organs, oral cavity and pharynx, oesophagus and prostate in a black South African population. Infectious Agents and Cancer 2007, 2:6.

10. Reiner WG, Walsh PC: An anatomical approach to the surgical management of the dorsal vein and Santorini's plexus during radical retropubic surgery. J Urol 1979, 121:198-200.

11. Walsh PC: Anatomic radical prostatectomy. Evolution of the surgical technique. J Urol 1998, 160:2418-2424.

12. Fuller E: Six successful and successive cases of prostatectomy. J Cutan Genitourin Dis 1895, 13:229-239. 
13. Culp DA: Benign prostatic hyperplasia: early recognition and management. Urol Clin North Am 1975, 2:29-48.

14. Montironi R, van der Kwast $T$, Boccon-Gibod L, Bono AV, Boccon-Gibod L: Handling and patology reporting of radical prostatectomy specimens. Eur Urol 2003, 44:626-636.

15. Rosai J: Rosai and Ackerman's Surgical Pathology Edinburgh: Mosby; 2004.

16. Eble JN, Kauter G, Epstein JI, Sesterhenn I: Pathology and genetics of tumours of the urinary system and male genital organs (IARC/World Health Organization Classification of Tumours). Lyon, France: IARC Press; 2003.

17. Epstein Il, Allsbrook WC, Amin MB, Egevad LL: ISUP Grading Committee: The 2005 International Society of Urological Pathology (ISUP) Consensus conference on Gleason grading of prostatic carcinoma. Am I Surg Pathol 2005, 29(9):1228-1242.

18. Sobin LH, Wittekind CH: TNM Classification of Malignant Tumours. 6 edition. Wiley; 2002.

19. Srigley JR, Amin MB, Epstein JI, Grignon DJ, Humphrey PH, Renshaw AA, Wheeler TM: Updated protocol for the examination of specimens from patients with carcinomas of the prostate gland. Arch Pathol Lab Med 2006, 130(7):936-946

20. Hamsikova E, Smahel M, Sapp M, Munoz N, Bosch FX, Shah KV, Vonka V: Correlation between the presence of anti HPV 33 VLP antibodies and HPV DNA in cervical neoplasia patients. Arch Virol 1997, 142(2):413-416.

21. von Elm E, Altman DG, Egger M, Pocock SJ, Gøtzsche PC, Vandenbroucke JP: The Strengthening the Reporting of Observational Studies in Epidemiology (STROBE) statement: guidelines for reporting observational studies. J Clin Epi 2008, 61:344-349.

22. Kirby RS, Patel MI: Fast facts: Prostate cancer Oxford: Health Press Limited; 2009 .

23. Amo FH, Cordero JMD, Tartajo FV, Hernandez FL, Carrillo AB, Burgos JG, Rios DS: Cáncer incidental de próstata. Actas Urol Esp 1999, 23(10):848-852.

24. Dillner J, Knekt P, Boman J, Lehtinen M, Geijersstam VA, Sapp M, Schiller J, Maatela J, Aromaa A: Sero-epidemiological association between humanpapillomavirus infection and risk of prostate cancer. Int J Cancer 1998, 75:564-567.

25. Korodi Z, Wang X, Tedeschi R, Knekt P, Dillner J: No serological evidence of association between prostate cancer and infection with herpes simplex virus type 2 or human herpesvirus type 8: a nested case-control study. J Inf Dis 2005, 191:2008-2011.

26. Huang WY, Hayes R, Pfeiffer R, Viscidi RP, Lee FK, Wang YF, Reding D, Whitby D, Papp JR, Rabkin CS: Sexually Transmissible Infections and Prostate Cancer Risk. Cancer Epidemiol Biomarkers Prev 2008, 17(9):2374-2381

27. Dennis KL, Coughlin JA, McKinnon BC, Wells TS, Gaydos CA, Hamsikova E, Gray GC: Sexually transmitted infections and prostate cancer among men in the U.S. Military. Cancer Epidemio Biomarkers Prev 2009, 18(10):2665-2671.

28. Sutcliffe S, Giovannucci E, Gaydos CA, Viscidi RP, Jenkins FJ, Zenilman JN, Jacobson LP, De Marzo AM, Willett WC, Platz EA: Serum antibodies against Chlamydia trachomatis, human papillomavirus, and human herpesvirus type 8 in relation to prostate cancer: a prospective study. Cancer Epidemiol Biomarkers Prev 2007, 16(8):1573-1580.

29. Adami HO, Kuper $\mathrm{H}$, Andersson SO, Bergström R, Dillner J: Prostate Cancer Risk and Serologic Evidence of Human Papilloma Virus Infection: A Population-based Case-Control Study. Cancer Epidemiol Biomarkers Prev 2003, 12:872-875.

30. Sutcliffe S, Viscidi RP, Till C, Goodman PJ, Hoque AM, Hsing AW, Thompson IM, Zenilman JM, De Marzo AM, Platz EA: Human papillomavirus types 16,18 and 31 serostatus and prostate cancer risk in the prostate cancer prevention trial. Cancer Epidemiol Biomarkers Prev 2010, 19(2):614-618.

31. Hayes RB, Pottern LM, Strickler H, Rabkin C, Pope V, Swanson GM Greenberg RS, Schönberg JB, Liff J, Schwartz AG, Hoover RN, Fraumeni JF Jr: Sexual behaviour, STDs and risks for prostate cancer. Br J Cancer 2000, 82(3):718-725

32. Rosenblatt KA, Carter JJ, Iwasaki LM, Galloway DA, Stanford JL: Serologic evidence of human papillomavirus 16 and 18 infections and risk of prostate cancer. Cancer Epidemiol Biomarkers Prev 2003, 12:763-768.

33. Ravich A, Ravich RA: Prophylaxis of cancer of the prostate, penis, and cervix by circumcision. NY State J Med 1950, 50:1519-1520.
34. Taylor ML, Mainous AG, Wells BJ: Prostate cancer and sexually transmitted diseases: a meta-analysis. Fam Med 2005, 37(7):506-512.

35. Stone KM, Karem KL, Sternberg MR, Mc Quillan GM, Poon AD, Unger ER, Reeves WC: Seroprevalence of Human Papillomavirus Type 16 Infection in the United States. J Infect Dis 2002, 186:1396-1402.

36. Giuliano AR, Tortolero-Luna G, Ferrer E, Burchell AN, de Sanjose S, Kjaer SK, Munoz N, Schiffman M, Bosch FX: Epidemiology of Human Papillomavirus Infection in Men, Cancers otherthan Cervical and Benign Conditions. Vaccine 2008, 26(Suppl 10):K17-K28.

37. Jeong WJ, Park SW, Shin M, Lee YJ, Jeon YK, Jung YH, Hah JH, Kwon TK, Song YS, Kim KH, Sung MW: Presence of HPV type 6 in dysplasia and carcinoma arising from recurrent respiratory papillomatosis. Head Neck 2009, 31(8):1095-1101.

38. González AB, Urban Ml, Sitas F, Blackburn N, Hale M, Patel M, Ruff P, Sur R, Newton R, Beral V: Antibodies against six human herpesviruses in relation to seven cancers in black South Africans: A case control study. Infectious Agents and Cancer 2006, 1:2 [http://www.infectagentscancer.com/ content/1/1/2]

39. Xu F, Schillinger JA, Sternberg MR, Johnson RE, Lee FK, Nahmias AJ, Markowitz LE: Seroprevalence and Coinfection with Herpes Simplex Virus Type 1 and Type 2 in the United States, 1988- 1994. J Infect Dis 2002, 185:1019-1024.

40. Smith JS, Robinson NJ: Age-specific prevalence of infection with herpes simplex virus types 2 and 1: a global review. J Infect Dis 2002, 186(Suppl 1):S3-28.

41. Samanta M, Harkins L, Klemm K, Britt WJ, Cobbs CS: High prevalence of human cytomegalovirus in prostatic intraepithelial neoplasia and prostatic carcinoma. J Urol 2003, 170:998-1002.

42. Staras SAS, Dollard SC, Radford KW, Flanders WD, Pass RF, Cannon MJ: Seroprevalence of cytomegalovirus infection in the United States, 19881994. Clin Inf Dis 2006, 43:1143-1151.

43. Wagenlehner FME, Weidner W, Naber KG: Chlamydial infections in urology. World J Urol 2006, 24:4-12.

44. Stamm WE: Chlamydia trachomatis Infections: Progress and Problems. J Inf Dis 1999, 179(Suppl 2):S380-383.

45. Kramer G, Mitteregger D, Marberger M: Is Benign Prostatic Hyperplasia (BPH) an Immune Inflammatory Disease? Eur Urol 2007, 51:1202-1216.

46. Palapattu GS, Sutcliffe S, Bastian PJ, Platz EA, De Marzo AM, Isaacs WB, Nelson WG: Prostate carcinogenesis and inflammation: Emerging insights. Carcinogenesis 2004, 26:1170-1181.

47. Takeyama K, Mitsuzawa H, Shimizu T, Konishi M, Nishitani C, Sano H, Kunishima Y, Matsukawa M, Takahashi S, Shibata K, Tsukamoto T, Kuroki Y: Prostate cell lines secrete IL-8 in response to Mycoplasma hominis through toll-like receptor 2-mediated mechanism. Prostate 2006, 66:386-391.

48. Namiki K, Goodison S, Porvasnik S, Allan RW, Iczkowski KA, Urbanek C, Reyes L, Sakamoto N, Rosser CJ: Persistent exposure to Mycoplasma induces malignant transformation of human prostate cells. PLOS ONE 2009, 4(9):e6872

49. Sutcliffe S, Giovannucci E, De Marzo AM, Leitzmann MF, Willett WC Platz EA: Gonorrhea, Syphilis, Clinical Prostatitis, and the Risk of Prostate Cancer. Cancer Epidemiol Biomarkers Prev 2006, 15(11):2160-2166.

\section{Pre-publication history}

The pre-publication history for this paper can be accessed here: http://www.biomedcentral.com/1471-2407/11/53/prepub

doi:10.1186/1471-2407-11-53

Cite this article as: Hrbacek et al: Serum antibodies against genitourinary infectious agents in prostate cancer and benign prostate hyperplasia patients: a case-control study. BMC Cancer 2011 11:53. 